$\left.\begin{array}{c}\text { Sournals } \\ \text { INTERNATIONAL JOURNAL OF } \\ \text { ORGANIZATIONAL LEADERSHIP }\end{array}\right) \begin{gathered}\text { INDUSTRIAL } \\ \text { MANAGEMENT } \\ \text { INSTITUTE }\end{gathered}$

\title{
An investigation into the impact of ethics on reinforcing organizational citizenship behavior in arts and cultural clubs of the mosques in Esfahan
}

\author{
Razieh Fayyaz $^{1 *}$, Maryam Azizinia ${ }^{2}$ \\ ${ }^{1} \mathrm{PhD}$ Student of Management and Cultural Planning, Islamic Azad University, Khorasgan Branch \\ ${ }^{2} \mathrm{MA}$ in Cultural Management
}

\begin{abstract}
Keywords:

Ethics, Professional ethics, Organizational citizenship behavior

Received

05 November 2015

Received in revised form 07 June 2016

Accepted

08 June 2016

Correspondence:

ra.fayaz@yahoo.com

Organizational citizenship behavior is sort of ethical behavior, which is considered as an inevitable necessity for effective organizational performance. The aim of this study was to investigate the impact of ethics on reinforcing organizational citizenship behavior. The study is an applied research adopting a survey design. The statistical population included 300 managers of arts and cultural clubs of the mosques in Esfahan in 2014-15. As statistical sample, 150 managers were selected by means of Cochran's formula. The data collection tool was a researcher-made questionnaire (Cronbach's Alpha= 0.83). The content validity of questionnaire was confirmed by experts and professors. The results indicated that from the viewpoint of respondents, the impact of organizational ethics on citizenship behavior is above average. Therefore, according to the results of statistical analyses, all the hypotheses of this research are confirmed and paying attention to ethical issues can improve the performance of the organization. Moreover, organizations' adherence to ethics has a positive impact on different dimensions of organizational citizenship behavior.
\end{abstract}

(c)AIMI Journals

\section{Introduction}

Ethics are a collection of human's spiritual and inward qualities and are revealed as actions and behavior which are derived from human's inner ethos, thus it is said that ethics can be defined through their effects. Today, paying attention to ethics and ethical values in analyzing the behavior of organizations is essential. On the other hand, organizational citizenship behavior is a new issue in organizational behavior that is of great importance. Organizational citizenship is an idea and includes various behaviors of employees like accepting and carrying extra responsibilities, obeying rules and approaches of the organization, developing positive attitude, being patient, and tolerating dissatisfaction and problems in the organization. According to the 
organizational theories, organizational citizenship behavior definitely contributes to the competition, performance, and efficiency of organizations through resource evolution, innovations, and adjustability (Kordnaiej, Khanifar, Zeraatkar, \& Alashti, 2012). Since ethics has a great impact on organization's efficiency and success, in this research the impact of ethics on reinforcing organizational citizenship behavior has been investigated. The results of this study are of great importance because ethics are considered as a need for today's organizations and organizational citizenship behavior is sort of ethical behavior.

\section{The Literature Review}

The changing circumstances, increased competition, and the importance of efficiency reveal the need of organizations to a valuable generation of employees. These employees are called organizational soldiers and they differentiate between effective organizations and ineffective organizations, since they consider the organization as their homeland and do their best to accomplish the goals of their organization. Today, in the literature of organization and management science, these attempts are called organizational citizenship behavior (Zeinabadi, Behrangi, Naveebrahim, \& Farzad, 2008). Undoubtedly, these employees differentiate between effective organizations and ineffective organizations (Podsakoff, Mackenzie, Paine, \& Bachrach, 2000). Organ (1988, as cited in Cohen \& Kol, 2004) defines organizational citizenship behavior as "individual behavior that is discretionary, not directly or explicitly recognized by the formal reward system and that in the aggregate promotes the effective functioning of the organization”.

Organizations cannot develop the efficiency of their wisdom of crowds without individuals' voluntary tendency to cooperate, thus, the difference between voluntary cooperation and involuntary cooperation is of great importance. In fact, in involuntary and obligatory cooperation, individuals carry their responsibilities according to rules, regulations, and standards of an organization, however, in voluntary cooperation, they cooperate beyond their responsibilities and devote their attempt and energy to the benefit of the organization. In this case, people sacrifice their individual benefits for collective benefits (Tabarsa, Hadizadeh Moghaddam, \& Keshtegar, 2010).

Organizational citizenship behavior can be defined as sort of behavior beyond what has been officially specified for the employees of the organization or sort of voluntary behavior based on personal volition. Organizational citizenship behavior is not directly or explicitly recognized by the formal reward system and it is of great importance for the performance efficiency and success of the organization (Castro, Armario, \& Ruiz, 2004). Graham (1991, as cited in Bienstock, DeMoranville, \& Smith, 2003) believes that citizenship behavior in the organization is of three kinds, namely organizational obedience, organizational loyalty, and organizational cooperation which are touched upon briefly below.

Organizational Obedience: This term describes the behavior which its necessity has been identified and accepted in a reasonable structure of regulations. The indices of organizational obedience include behavior like respecting organizational rules and carrying responsibilities with regard to organizational resources. 
Organizational Loyalty: This kind of loyalty to the organization is different from loyalty to self, other individuals, and organizational units and sections and describes the employees' loyalty to organizational benefits and support for the organization.

Organizational Cooperation: This term refers to individuals' involvement in managing an organization such as attending meetings, sharing ideas with other people, and being aware of the issues within the organization (Bienstock et al., 2003). According to Organ (1988), organizational citizenship behavior has five dimensions, which includes conscientiousness, altruism, civic virtue, sportsmanship, and courtesy. In conscientiousness, the members of the organization work beyond their responsibilities, while altruism refers to useful behavior such as cordiality and sympathy, so that colleagues will help one another in trouble directly or indirectly. Civic virtue includes behavior such as engaging in extracurricular activities, when it is unnecessary, supporting the changes presented by the managers of the organization, reading books and magazines in order to enhance the general information, and hanging posters and notifications in the organization to inform people. Sportsmanship refers to tolerance towards irritable situations without any objection. Finally, courtesy is defined as how to behave towards colleagues, supervisors and clients.

Researching such behavior requires building infrastructure and in order to do this, ethics are essential, because rules and regulations cannot individually administer the organizations. Since individuals' ethical performance has great impacts on the whole performance of the organization, adhering to ethics is of primary importance. Therefore, these two concepts have much in common, which finding these common points and focusing on them will lead to organization's success. Ethics are always of great importance, because they improve the relationship between individuals. In management, these inner mechanisms can create ethical performances without the need for outer levers. The role of ethics in performances and behavior, in decision-making and choices, and in interactions and communications is prominent, thus, today, ethics and management is considered as an important field in management (Beikzad, Sadeghi, \& Ebrahimpour, 2012). Although ethical behavior may be related to external consequences like clientele's satisfaction or organization's reputation, it can also be related to internal consequences like increasing employees' organizational citizenship behavior. The employees, who exhibit more ethical behavior, involve more in meta-role or meta-duty activities. Ethical behavior can prepare the general atmosphere of the organization for exhibiting citizenship behavior (Baharifar, Javaheri Kamel, \& Ahmadi, 2011).

There are various definitions for ethics which some of them are summarized here: Ethics are those principles, which define right and wrong behavior and differentiate between them (Soltani, 2008). They are a system of values and do's and don'ts which differentiate between good and bad (Alvani, 2004).According to Connock and Johns (1995, as cited in Abzari \& Yazdanshenas, 2007), ethics are defined as fairness and rightness and deciding what is right or wrong. Moreover, they are related to activities, which underpin accountable behavior. Ethics are also a communication model based on observing the right of the other side. In other words, ethics are defined as being accountable to individuals' rights (Gharamaleki, 2008).Ethics are spiritual principles and values based on right or wrong behavior. Ethics include concepts of trust, honesty, truth, keeping a promise, loyalty, respect, responsibility, and commitment to 
others, justice, citizenship virtue, and serving the organization and society (Siadat, Nasr Esfahani, \& Allahyari, 2010).Professional ethics are one of the new branches of ethics which try to answer ethical issues of different professions and consider special principles for them (Hartog \& Winstanley, 2002).Professional ethics are common behavior among the people who work in a profession. They are the human's behavior and action management when he or she is doing a professional career. Professional ethics are also a field in ethics science which study job relationships and a set of rules that are obtained from the nature of the profession.

There are various theories on ethical action including altruism, essential goodness and badness, and inspiration of consciousness, Darwinism, and God's satisfaction. According to altruism theory, any sort of action in the field of altruism is called ethical action. In fact, the criterion for ethical action is self-sacrifice. The problem with this theory is that altruism may sometimes be instinctive and natural, thus, it cannot always be an ethical action. The followers of essential goodness and badness theory believe that human's mind can understand the essential goodness of ethical actions and essential badness of unethical actions. Ethical actions are done based on human's mind and ethical humans are those who act according to their mind, not lust, indignation, and fear. In the theory of inspiration of consciousness, any action, which originates from inspiration and consciousness, is an ethical action and any action that involves other things is not called ethical. The theory of Darwinism is based on struggle for existence, i.e. struggle is more preferable than cooperation. According to God's satisfaction theory, an action is justifiable when it is supported by a religious belief (Khanifar \& Zarvandi, 2009). Some of the advantages of ethics in management include the development of human's potential abilities and transform them into actual abilities in the organization, freedom from machinism and dominance over machine, freedom from organizational destructive tension, which is mainly derived from position and administrative proceedings (this tension modifies managers' good behavior and transforms it into bad behavior). Finally, if ethical guidance is followed, managers will accept social and human responsibilities (Samadi \& Mahdavikhou, 2009).

Denhardt (1991) considers three components for the charter of ethics, i.e. honor, benevolence, and justice. He believes that managers and administrators must avoid tarnishing anyone's reputation, must be benevolent, and practice justice. In fact, ethics must guarantee these items (Salehnia \& Allahtavakkoli, 2009). According to Petti and Charles (2008, as cited in Soleimani, Abbaszadeh, \& Niazazari, 2012), the four dimensions of work ethics include interest in job, human relationships in workplace, diligence, and cooperation in working. Goran and Wood (2004, as cited in Moghimi, 2008) have divided the codes of ethics in public organizations into seven dimensions, namely philosophy and theories, workplace, leadership accountability, employees' accountability, equity, tendency to people, and other ethical issues.

For those organizations who want to improve their ethical principles or establish new principles, there are global business standards which are the summary of guidance principles of large global companies. These principles are divided into eight categories, i.e. the principles of trusteeship, ownership, credibility and trust, transparency, status, equity, citizenship, and mutual sensitivity (Khanifar \& Zarvandi, 2009).

Soltani (2012) has summarized the standards of employees' ethical assessment in 10 principles. Regarding the principle of trusteeship, we must be trustworthy and loyal towards the company's activities. The principle of ownership involves respecting individuals' ownership 
and rights, avoiding embezzlement and extravagance, and developing commitment to physical, consumable, and human benefits. Following this, the principle of credibility and trust includes promise and commitment. The principle of transparency refers to working honestly and keeping the record of activities and work processes. Moreover, the principle of status is concerned with showing people the proper respect and includes health, safety, privacy, and human rights. The principle of equity concerns entering the free and fair competition and respecting individuals' opinions. It also includes equity in transaction or in behavior. The principle of citizenship involves accountability, complying with the rules, and protecting public property. The principle of sensitivity includes sensitivity to human resource needs, feeling empathy, paying attention to people's concerns, and public partnership. Finally, the principle of religious and Islamic precepts and the principle of etiquette are also important.

Sohrabi and Khanlori (2009) investigated the role of organizational citizenship behavior in the ethics of information technology. They found that the ethics of information technology could be influenced by organization's ethical values. In fact, organizational commitment and the dimensions of organization's citizenship behavior act as mediators. In a research under the title of “An investigation into the consequences of organization's ethical values”, Baharifar and Javaheri Kamel (2010) concluded that organizational ethical values have a positive impact on individuals, commitment has a positive impact on ethical behavior, and ethical behavior has a positive impact on sportsmanship and altruism dimensions of organizational citizenship behavior.

In another research by Soleimani (2012), it was concluded that there is a positive and significant relationship between managers' ethical behavior and the organizational citizenship behavior of teachers and employees. Moreover, there is a positive and significant relationship between every dimension of ethical behavior and organizational citizenship behavior and its dimensions. Turnipseed (2002) investigated the relationship between organizational citizenship behavior and personal ethics. He considered organizational citizenship behavior as the good soldier syndrome and stated that the basis of such behavior is ethics. He also found high correlations with more ethical individuals being rated higher on organizational citizenship behavior. Baker, Hunt, and Andrews (2006) in their research under the title of "Promoting ethical behavior and organizational citizenship behaviors" among 489 members of a regional chapter of the National Association of Purchasing Managers in USA stated that organization plays a key role in employees' personal behavior. Moreover, ethical values can influence the key variables of organization which lead to higher levels of ethical behavior in the organization. They also found that higher levels of ethical behavior have a positive relationship with organizational citizenship behavior. Herrbach and Mignonac (2007) in their research indicated that managers' ethical values have a positive impact on all the organizational outcomes and have a direct and significant relationship with procedural justice, organizational commitment, job satisfaction, and adaptive behavior of employees. Zoghbi-Manrique-de-Lara and Melian-Gonzalez (2009) in the research under the title of "The role of anomia on the relationship between organizational justice perceptions and organizational citizenship online behaviors” concluded that anomic feelings (when there are no social and ethical standards) intensify the negative effects of organizational citizenship behavior. Wang and Wong (2011) in their research found that organizational approaches such as job satisfaction, organizational 
commitment, and perceived organizational support by the organization could predict organizational citizenship behavior. Mooghali, Seyedjavadin, Ahmadi, and Alavi (2013) conducted a research under the title of "An explanatory model of Islamic work ethics and organizational citizenship behavior due to job values”. According to the results, Islamic work ethics significantly affected employees' viewpoint and made them behave appropriately in the organization. Furthermore, individual and collective values in workplaces were in line with the increased social attention to human and ethical values. Finally, Islamic work ethics with the mediation of job values had impacts on organizational citizenship behavior. Ahmadi, Nami, and Barvarz (2014) in their research indicated that spirituality in workplace has relationship with employees’ organizational citizenship behavior and predicts it.

\section{Research Hypotheses \\ Main Hypothesis}

The following main hypothesis guided the study:

H: Organizational ethics has an impact on organizational citizenship behavior.

\section{Secondary Hypotheses}

Secondary hypotheses of the study are as follows:

$\mathbf{H}_{\mathbf{1}}$ : The dimension of religious precepts has an impact on organizational citizenship behavior.

$\mathbf{H}_{2}$ : The dimension of etiquette has an impact on organizational citizenship behavior.

$\mathbf{H}_{3}$ : The dimension of trust has an impact on organizational citizenship behavior.

$\mathbf{H}_{\mathbf{4}}$ : The dimension of trusteeship has an impact on organizational citizenship behavior.

$\mathbf{H}_{5}$ : The dimension of ownership has an impact on organizational citizenship behavior.

$\mathbf{H}_{\mathbf{6}}$ : The dimension of transparency has an impact on organizational citizenship behavior.

$\mathbf{H}_{7}$ : The dimension of status has an impact on organizational citizenship behavior.

$\mathbf{H}_{\mathbf{8}}$ : The dimension of equity has an impact on organizational citizenship behavior.

$\mathbf{H}_{\mathbf{9}}$ : The dimension of citizenship has an impact on organizational citizenship behavior.

$\mathbf{H}_{10}$ : The dimension of sensitivity has an impact on organizational citizenship behavior.

\section{Method}

The statistical population included the managers of arts and cultural clubs of the mosques in Esfahan (300 individuals). As statistical sample, 150 managers were selected by means of Cochran's formula. The data collection tool was a researcher-made questionnaire. The reliability of questionnaire was 0.83 and its validity was measured through content method, i.e. the questionnaire was given to the experts and professors of the university and then its validity was confirmed. The questionnaire consisted of 54 questions based on Likert scale. To address the problem, 11 hypotheses were proposed and the data was analyzed through SPSS software at two levels of descriptive statistics (frequency indices) and referential statistics (student's t-test).

\section{Results}

In this part of statistical analysis, we investigate the distribution of statistical samples in terms of variables like respondents' gender, level of education, age, and length of service. According to descriptive findings, $90 \%$ of respondents were men and $10 \%$ were women. Most of the 
respondents (33.3\%) had BA and 34.0\% were between 31 and 40 years old. Moreover, the longest length of service was between 6 to 10 years (48\%). Table 1 shows the frequency and percent of respondents' gender. Table 1 shows the profile of participants.

Table 1

Profile of Participants

\begin{tabular}{|c|c|c|c|}
\hline Gender & percent & Age & percent \\
\hline Male & 10.0 & 20 to 30 Years Old & 31.3 \\
\hline \multirow[t]{2}{*}{ Female } & 90.0 & 31 to 40 years Old & 34.0 \\
\hline & & 41 to 50 Years Old & 30.7 \\
\hline Education & & 51 Years Old and Higher & 4.0 \\
\hline Under Diploma & 4.0 & & \\
\hline Diploma & 24.7 & Work Experience & \\
\hline Associate Degree & 32.0 & Under 5 Years & 23.3 \\
\hline BA & 33.3 & 6 to 10 Years Old & 48.0 \\
\hline \multirow[t]{2}{*}{ MA and Higher } & 6.0 & 11 to 15 Years Old & 12.0 \\
\hline & & 16 Years and Higher & 16.7 \\
\hline
\end{tabular}

The results of descriptive statistics of respondents' opinions on the impact of ethics on organizational citizenship behavior indicated that the mean was 4.09 and SD was 0.37.

Table 2

One-Sample T-Test for Exchange Rate

\begin{tabular}{crrrrrr}
\hline \multicolumn{5}{c}{ Test value $=3$} \\
\hline Title & T-Statistics & $\begin{array}{c}\text { Degrees of } \\
\text { Freedom }\end{array}$ & Significance Level & $\begin{array}{c}\text { Compare } \\
\text { Means }\end{array}$ & Low Limit & High Limit \\
\hline Organizational Ethics & 35.776 & 149 & 0.000 & 1.09080 & 1.0306 & 1.1510 \\
\hline $\mathrm{P}<0.05$ & & & & &
\end{tabular}

According to Table 2, at alpha level of 0.05 , the significance value for the impact of organizational ethics on organizational citizenship behavior from the viewpoint of respondents is lower than 0.05. Since both low and high limits at confidence interval of $95 \%$ are positive and T-statistics is positive, too, the opinions of respondents are considered above average; thus, the research hypothesis about the impact of organizational ethics on organizational citizenship behavior is confirmed.

Table 3 indicates the descriptive statistics of respondents' opinions on the impact of organizational ethics dimensions on organizational citizenship behavior which the mean for 150 samples was between 3.976 and 4.197 .

Table 3

Descriptive Statistical Indices

\begin{tabular}{ccc}
\hline Title & Mean & SD \\
\hline Religious Percepts & 4.19 & 0.43 \\
Etiquette & 4.13 & 0.51 \\
Trust & 4.19 & 0.49 \\
Trusteeship & 4.07 & 0.80 \\
Ownership & 4.04 & 0.43 \\
Transparency & 4.04 & 0.98
\end{tabular}




\begin{tabular}{cll} 
Status & 4.01 & 0.46 \\
Equity & 3.97 & 0.50 \\
Citizenship & 4.15 & 0.82 \\
Sensitivity & 4.07 & 0.44 \\
\hline
\end{tabular}

Table 4 presents the one-sample $t$-test for exchange rate.

Table 4

One-Sample T-Test for Exchange Rate

\begin{tabular}{ccccc}
\hline Title & T-Statistics & Compare Means & Low Limit & High Limit \\
\hline Religious Percepts & 33.73 & 1.19 & 1.12 & 1.26 \\
Etiquette & 26.97 & 1.13 & 1.04 & 1.21 \\
Trust & 29.46 & 1.19 & 1.11 & 1.27 \\
Trusteeship & 16.31 & 1.07 & 0.94 & 1.20 \\
Ownership & 29.42 & 1.04 & 0.97 & 1.11 \\
Transparency & 12.96 & 1.04 & 0.88 & 1.20 \\
Status & 26.77 & 1.01 & 0.93 & 1.08 \\
Equity & 23.77 & 0.97 & 0.89 & 1.05 \\
Citizenship & 17.09 & 1.15 & 1.02 & 1.28 \\
Sensitivity & 29.37 & 1.07 & 0.99 & 1.14 \\
\hline
\end{tabular}

$\mathrm{P}<0.05$, Test Value $=3$, Confidence Interval 95\%

According to Table 4, at alpha level of 0.05 , the significance value for the impact of organizational ethics dimensions on organizational citizenship behavior from the viewpoint of respondents is lower than 0.05 . Since both low and high limits at confidence interval of $95 \%$ are positive and T-statistics is positive, too, the opinions of respondents are considered above average; thus, the secondary hypotheses about the impact of ethics dimensions (religious percepts, etiquette, trust, trusteeship, ownership, transparency, status, equity, citizenship and sensitivity) on organizational citizenship behavior are confirmed.

\section{Discussion and Conclusion}

The findings revealed that that there is a significant relationship between ethics and organizational citizenship behavior in the studied population and the opinions of respondents about the role of different dimensions of ethics in the dimensions of organizational citizenship behavior is above average. From the viewpoint of respondents, the prioritization of ethics dimensions in the studied population is trust, religious percepts, citizenship, etiquette, trusteeship, sensitivity, ownership, transparency, status, and equity. According to Table 7, from the viewpoint of the respondents, the dimension of trust, which has the value of 4.1987, is closer to the mean, thus, in the studied population, trust is more obvious. On the other hand, the dimension of equity had the lowest mean and is below average, therefore, the indices of this dimension must be reinforced in the organization.

Hence, successful organizations need employees who work more than their responsibilities and perform beyond the organization's expectations. Since organizational citizenship behavior is an ethical issue and ethical behavior builds the foundation of the organization, to reinforce organizational citizenship behavior, we must use ethical mechanisms. The success factor of today's organizations is their transformation into ethical organizations, so that they can prepare 
the grounds for organizational citizenship behavior. The results also indicated that employees' ethical behavior has a positive impact on organizational citizenship behavior. It can be claimed that if organizations assess their employees' ethical standards and reinforce the employees' ethics, they can achieve more success. According to the results of data analysis, the followings are recommended: Developing ethical indices and standards in the organization to assist individuals, explaining ethical indices and legalizing them, raising awareness about important ethical issues, emphasizing ethical values in the organization and operating ethical assessment system for employees, developing appropriate and operating indices for ethical assessment, creating conditions for applying ethical principles, encouraging employees to adhere to ethical principles, and finally considering ethics in employment system.

\section{References}

Abzari, M., \& Yazdanshenas, M. (2007). Social responsibility and work ethics in modern quality management. Culture Management, 5(15), 5-42.

Ahmadi, S., Nami, Y., \& Barvarz, R. (2014). The relationship between spirituality in the workplace and organizational citizenship behavior. Procedia - Social \& Behavioral Sciences, 114, 262-264.

Alvani, S. (2004). Ethics and management towards integrated system of ethics in the organization. Journal of Improvement \& Transformation Management Studies, 41/42, 1-11.

Baharifar, A., \& Javaheri Kamel, M. (2010). An investigation into the consequences of organization's ethical values (organizational justice, organizational commitment and organizational citizenship behavior). Police Human Development, 7, 95-118.

Baharifar, A., Javaheri Kamel, M., \& Ahmadi, S. (2011). Ethical behavior and organizational citizenship behavior: The effects of ethical values, justice and organizational commitment. Organizational Resources Management Research, 1(1), $23-42$.

Baker, T. L., Hunt, T. G., \& Andrews, M. C. (2006). Promoting ethical behavior and organizational citizenship behaviors: The influence of corporate ethical values. Journal of Business Research, 59(7), 849-857.

Beikzad, J., Sadeghi, M., \& Ebrahimpour, D. (2012). The impact of organizational factors on developing employees' professional ethics. Ethics in Science \& Technology, 7(2), 55-63.

Bienstock, C. C., DeMoranville, C. W., \& Smith, R. K. (2003). Organizational citizenship behavior and service quality. Journal of Services Marketing, 17(4), 357-378.

Castro, C. B., Armario, E. M., \& Ruiz, D. M. (2004). The influence of employee organizational citizenship behavior on customer loyalty. International Journal of Service Industry Management, 15(1), 27-53.

Cohen, A., \& Kol Y. (2004). Professionalism and organizational citizenship behavior: An empirical examination among Israeli nurses. Journal of Managerial Psychology, 19(4), 386-405.

Gharamaleki, A. F. (2008). An introduction to professional ethics. Tehran, Iran: Saramad Publication.

Hartog, M., \& Winstanley, D. (2002). Ethics and human resource management: Professional development and practice. Business \& Professional Ethics Journal, 21(2), 3-9.

Herrbach, O., \& Mignonac, K. (2007). Is ethical P-O fit really related to individual outcomes? A study of management-level employees. Business Society, 46(3), 304-330.

Khanifar, H., \& Zarvandi, N. (2009). Work ethics charter and adherence to ethical organization. Human Resource Management in Oil Industry, 8, 101-132.

Kordnaiej, A., Khanifar, H., Zeraatkar, S., \& Alashti, K. (2012). Spiritual intelligence and its relationship with organizational citizenship behavior (Case study: Islamic Republic of Iran Broadcasting). Organizational Resources Management Research, 2(2), 127-147.

Moghimi, S. (2008). Organizational ethics: The essence of efficient organizational culture. Journal of Organizational Culture Management, 6(17), 63-87.

Mooghali, A., Seyedjavadin, S., Ahmadi, S., \& Alavi, A. (2013). An explanatory model of Islamic work ethics and organizational citizenship behavior due to job values: Case study of Isfahan University of Medical Sciences, Iran. Journal of Health Information Management, 10(2), 1-10.

Organ, D. W. (1988). Organizational citizenship behavior: The good soldier syndrome. USA: Lexington Books. 
Podsakoff, P. M., Mackenzie, S. B., Paine, J. B., \& Bachrach, D. G. (2000). Organizational citizenship behaviors: A critical review of the theoretical and Empirical literature and suggestions for future research. Journal of Management, 26(3), 513563.

Salehnia, M., \& Allahtavakkoli, Z. (2009). Organizational ethics with an emphasis on ethical charter. Ethics in Science \& Technology, 4(3/4), 66-78.

Samadi, A., \& Mahdavikhou, R. (2009). An investigation into the impact of management ethics on employees’ organizational commitment in Tax Admission Organization of Hamedan province. Journal of Tax Research, 17(4), 45-71.

Siadat, S., Nasr Esfahani, A., \& Allahyari, S. (2010). Ethical leadership in educational organizations. Cultural Engineering, 45/46, 38-46.

Sohrabi, B., \& Khanlori, A. (2009). Ethics, information technology and organizational citizenship behavior. Ethics in Science \& Technology, 4(1/2), 1-10.

Soleimani, N. (2012). An investigation of the relationship between managers' ethical behavior and the organizational citizenship behavior of teachers and employees in the schools of Garmsar County. Journal of Modern Thoughts in Education, 7(1), 11-27.

Soleimani, N., Abbaszadeh, N., \& Niazazari, B. (2012). The relationship between work ethics and employees' job satisfaction and job stress in the organization. Quarterly Journal of New Approaches in Educational Administration, 3(1), 21-38.

Soltani, I. (2008). Self-assessment tools and improvement in human resource management. Esfahan, Iran: Arkane Danesh Publication.

Soltani, I. (2012). Ethical excellence model. Esfahan, Iran: Arkane Danesh Publication.

Tabarsa, G., Hadizadeh Moghaddam, A., \& Keshtegar, A. (2010). Presenting a model for explaining the effective factors in organizational citizenship behavior. Journal of Public Administration Perspective, 1(1), 101-114.

Turnipseed, D. L. (2002). Are good soldiers good? Exploring the link between organization citizenship behavior and personal ethics. Journal of Business Research, 55(1), 1-15.

Wang, J., \& Wong, C. K. (2011). Understanding organizational citizenship behavior from a cultural perspective: An empirical study within the context of hotels in Mainland China. International Journal of Hospitality Management, 30(4), 845-854.

Zeinabadi, H., Behrangi, M., Naveebrahim, A., \& Farzad, V. (2008). Organizational citizenship behavior of teachers: Analysis of nature, methodology, antecedents, and consequences of internationally published researches in this area. Quarterly Journal of Educational Innovations, 7(4), 75-110.

Zoghbi-Manrique-de-Lara, P., \& Melian-Gonzalez, S. (2009). The role of anomia on the relationship between organizational justice perceptions and organizational citizenship online behaviors. Journal of Information, Communication, and Ethics in Society, 7(1), 72-85. 